\title{
FEE-FISHING UNITS IN THE BASIN OF CORUMBATAII: SOCIOECONOMIC-ENVIRONMENTAL DIAGNOSIS AND TREATMENT OF EFFLUENT
}

\author{
UNIDADES DE PESQUE-PAGUE NA BACIA DO RIO \\ CORUMBATAÍ: DIAGNÓSTICO SOCIOECONÔMICO- \\ AMBIENTAL E TRATAMENTO DE EFLUENTE
}

\author{
Sâmia Maria Tauk-Tornisielo \\ ${ }^{1 .}$ Centro de Estudos Ambientais, UNESP. Av. 24-A, 1515 - Bela Vista, CEP: 13506- \\ 900, Rio Claro, SP - Fone 19-3526-9394. e-mail: seb@rc.unesp.br
}

\begin{abstract}
This study was concerned to distinguish the main environmental and socio-economic aspects of 16 fee-fishing located in the Corumbataí river basin, São Paulo. Together, it verified the possibility of effluent treatment system with these units constructed wetlands system (CWS). Previously, it collected information on the number, location and diversity of activities of fee-fishing, as different government agencies and institutions did not have that information. Questionnaires were applied to collect information about the socio-economic and environmental aspects of fee-fishing units located in Corumbatai river basin. Were determinate abiotic and biotic factors present in water and effluent from the tanks of fee-fishing. It was applied a principal component analysis to the values of these factors monitored. The results showed that despite being a tourist attraction for the region and there is a considerable frequency of tourists on fee-fishing, it is still an activity that is economically unstable in Corumbataí River Basin. The results of the tests performed were compared with the limits for class 2 freshwater by CONAMA Resolution 357/05. These results showed that most of the values of the factors studied were above the limit established by this resolution, showing deterioration of water quality of the fee-fishing in this study. From an environmental standpoint, the fish-pay were considered potentially polluting sources, characterized by higher values of total nitrogen, ammonia, nitrite, nitrate, conductivity, turbidity, total phosphorus and microorganisms. The presence of excessive nutrients in the effluents in water is responsible for eutrophication and may indicate impairment of water quality of rivers in the basin study. Thus, the effluents from fishyou may pay in need of treatment, such as stabilization ponds and wastewater treatment systems using aquatic weeds before they are discarded into the environment.

Keywords: Environmental impacts. Corumbataí river basin. Fee-fishing. Socio-economic aspects.
\end{abstract}

\section{RESUMO}

Neste estudo preocupou-se caracterizar os principais impactos ambientais e os aspectos socioeconômicos de 16 pesque-pague localizados na bacia do rio Corumbataí, SP. Juntamente, foram verificadas as possibilidades de tratamentos de efluentes destas unidades com o sistema construído 
de áreas alagadas. Previamente foram coletadas informações do número, localização e diversidade de atividades dos pesque-pague, uma vez que diferentes órgãos governamentais e instituições não possuíam essas informações. Foram aplicados questionários para coletar informações quanto aos aspectos sócio-econômicos e ambientais dos pesque-pague localizados na bacia do rio Corumbataí, estado de São Paulo. Os resultados demonstraram que apesar de ser uma atração turística para a região e ocorrer uma freqüência considerável de turistas nos pesque-pague, ainda é uma atividade que se encontra instável economicamente na bacia do rio Corumbataí. Foram determinados fatores abióticos e bióticos presentes nas águas e nos efluentes dos reservatórios dos pesque-pague. Foi aplicada uma análise de componentes principais aos valores destes fatores dos pesque-pague monitorados. Os resultados das análises realizadas foram comparados com os limites estabelecidos para água doce de classe 2 pela Resolução CONAMA 357/05. Os resultados demonstraram que a maioria dos valores dos fatores estudados esteve acima do limite estabelecido por esta Resolução, demonstrando deterioração da qualidade de água dos pesque-pague em estudo. Do ponto de vista ambiental, os pesque-pague foram considerados fontes potencialmente poluidoras, caracterizados pelo aumento dos valores de nitrogênio total, amônia, nitrito, nitrato, condutividade, turbidez e fósforo total. A presença de nutrientes em excesso nos efluentes lançados na água é responsável pela eutrofização e pode indicar comprometimento da qualidade da água dos rios da bacia em estudo. Dessa forma, os efluentes provenientes de pesque-pagues necessitam de tratamento, como lagoas de estabilização ou sistemas de tratamento de efluentes utilizando-se macrófitas aquáticas, antes de serem descartados para o ambiente.

Palavras-chave: Impactos ambientais. Bacia do rio Corumbataí. Pesque-pague. Aspectos socioeconômicos.

\section{INTRODUCTION}

Among the many of the anthropic activities is aquaculture, which, in a manner of speaking, is the converse of agriculture, is a recent activity. Although the merit of aquaculture in relation to its high efficiency food production is recognized, its environmental impacts on natural systems receiving its effluents have also been identified. Aquaculture is a generic term that covers a wide variety of techniques of cultivation under different conditions and in species geographic locations.

In Brazil, the accelerated development of aquaculture has attracted people with little or no knowledge in the area and created a mechanism for negative impact. Consequently, aquatic biota has been affected. Implementing cropping systems could modify the environmental conditions and lead to changes in the flora, fauna, microbiotics, sediments, and in many cases, the local climate to say the least (SIPAÚBA-TAVARES, 2000).

Fee-fishing units are commercial ventures that exploit the popular desire for fishing, possess the potential to spread sources of allochthonous species in rivers - since leaks are almost inevitable and usually involve individuals that have already developed and are able to colonize the new environment. Besides, leaks may occur of the young of small species breeding in captivity (FERNANDES et al., 2003).

There are reports of escapes into natural environments of exotic species, such as four species of carp, namely the headstrong, Aristichthys nobilis, [Richardson (1845)], the common Cyprinus carpio carpio, [Linnaeus, 1758], the silver, Hypophthalmichthys molitrix [Valenciennes, 1844], and the grass, Ctenophatyngodon idellus [Valenciennes, 1844]. There is evidence that strengthens the hypothesis that during periods of heavy rainfall and high freshwater outflow, exotic species are easily transported into surrounding water resources of tank cultivation (GARCIA et al., 2004).

In the last decade, there was a conspicuous expansion in the number of fee-fishing units in Brazil. Environmental agencies responsible for monitoring this activity do not always maintain 
accurate records of the numbers and locations of these establishments. There is no effective control, supervision and monitoring of these units (FERNANDES et al., 2003).

The availability of few entertainment options in large cities and metropolitan areas has favored the development and expansion of activities such as sport fishing on fee-fishing (VENTURIERI, 2002; KUBITZA, 2003). Eler et al. (2001) cited that the economic success of this recreational activity depends on the maintenance of water quality, which is influenced by several factors such as the origin or source of water and feed management.

\section{MATERIAL AND METHODS}

\subsection{Fee-fishing in Corumbataí River Basin}

The fee-fishing units in the Corumbataí river basin were studied for their environmental- and socio-economic aspects. They were located with GPS - in 2005, when this was a new tool-and their distribution marked on a map of scale 1:50,000; it initially identified 16 fee-fishing units being set up in this basin (Figure 1). The Corumbataí river basin, with its source in the region of southeastern Brazil, and the entire region between Ipeúna and Rio Claro, is an area with high sedimentation and accelerated erosion. Palma-Silva and Tauk-Tornisielo (2001) found that the major environmental impacts were felt in this basin.

The most prominent difficulties were the lack of records of fee-fishing in municipal or bodies (Department of Water and Electricity and others). It was very difficult to identify fee-fishing units at the stage of registration, track the movements of the operators and contact them for collection of data; random searches of the routes were required between the cities of the river along the Corumbatai basin. Many of the fee-fishing phones had not been identified; one closed down during the studies and another was leased out. Another difficulty was in communicating with the owners, as some employees did not know to provide correct information.

\subsection{Physic-Chemical Aspects of Water in Fee-fishing Reservoirs}

Analyses of water were performed by the automated method as well as direct reading of indicators such as the water temperature $\left({ }^{\circ} \mathrm{C}\right)$, dissolved oxygen $\left(\mathrm{mg} . \mathrm{L}^{-1}\right)$, conductivity $\left(\mu \mathrm{S} . \mathrm{cm}^{-1}\right)$, transparency $(\mathrm{cm}), \mathrm{pH}$, salinity $(\% \mathrm{O})$, total dissolved solids $\left(\mathrm{mg}_{\mathrm{L}} \mathrm{L}^{-1}\right)$, apparent color $(\mathrm{PtCo})$, and turbidity (UNT). Using various other methodologies we determined the values of alkalinity $\left(\mathrm{mg} . \mathrm{L}^{-1}\right)$, nitrite $\left(\mathrm{mg} . \mathrm{L}^{-1}\right)$, nitrate $\left(\mathrm{mg} . \mathrm{L}^{-1}\right)$, ammonia $\left(\mathrm{mg} . \mathrm{L}^{-1}\right)$, total nitrogen $\left(\mathrm{mg} . \mathrm{L}^{-1}\right)$, total phosphorus $\left(\mu \mathrm{g} . \mathrm{L}^{-1}\right)$, dissolved phosphorus $\left(\mu \mathrm{g} . \mathrm{L}^{-1}\right)$, inorganic phosphate $\left(\mu \mathrm{g} . \mathrm{L}^{-1}\right)$, suspended solids $\left(\mathrm{mg} . \mathrm{L}^{-1}\right)$, and chemical oxygen demand - COD $\left(\mathrm{mg} . \mathrm{L}^{-1}\right)$.

After this partition water quality analysis in the six ponds was carried out and monitoring being conducted every two months using nine samples each. In ponds supplied by artesian wells, samples were obtained from the inlet and outlet of the ponds. In ponds supplied by mines, it was possible to sample the water only in the outlet from the ponds. Samples were taken from a depth of $15 \mathrm{~cm}$ in 1-L polyethylene bottles, taken to the laboratory, and immediately frozen until the moment of analysis. 


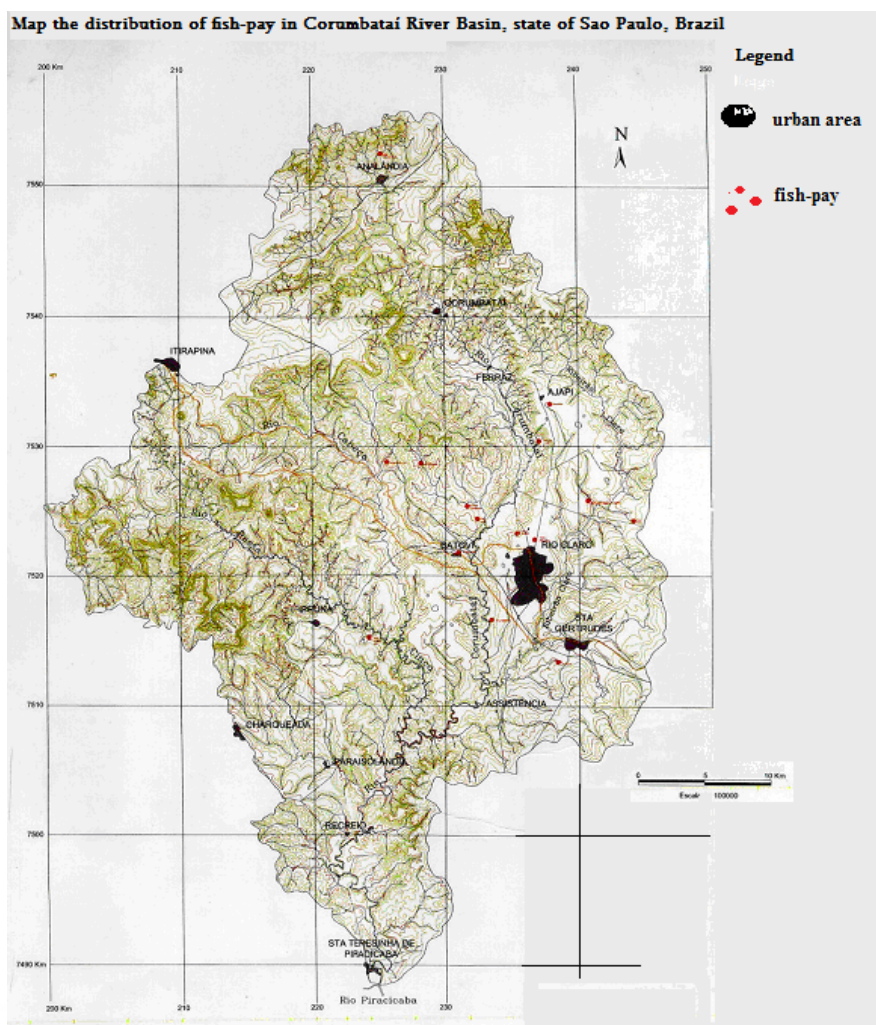

Figure 1. Map of the distribution of fee-fishing units in Corumbataí river basin, state of São Paulo, Brazil

The values of dissolved oxygen, $\mathrm{pH}$, temperature, and electrical conductivity were registered using a multiparameter meter (YSI, 556 MPS) at the time of sampling. Transparency was determined using a Secchi disk and turbidity by a turbidimeter (HACH®, 2100P). Total phosphorus was determined according to the procedure of Golterman et al. (1978), and total nitrogen, nitrite, and nitrate were estimated according to the method of Mackereth et al. (1978). The values for the ammonium ion were measured by the procedure described by Koroleff (1983). One way ANOVA analysis was applied to physical and chemical variables to compare sites (ponds) and seasons (dry and rainy). When the mean variations were different, the Tukey (SAS software 6.0) was employed. Significance level was $\mathrm{p}=0.05$.

In addition to the comparison of the mean values, the values of the parameters of both inlet water and effluents from the fee-fishing were compared with the limits fixed by the Conselho Nacional do Meio Ambiente or CONAMA Resolution 357/05 (BRASIL, 2005) for class 2 waters, which are the water bodies used for aquaculture operations.

\subsection{Biological Aspects of Water and Effluents of Fee-Fishing Reservoirs}

The methods it used in the analysis of microbiological and biological variables were total coliforms and Escherichia coli by Colilert (APHA, 1998), toxicity using Daphnia similis (CETESB, 1991), total pigments with filter glass fiber Whatman GF/F (mesh 1,2mm), vacuum pump, extraction with $80 \%$ ethanol, and hot reading by spectrophotometer (MARKER et al., 1980), and biochemical oxygen demand - BOD 5 days (APHA, 1998).

\subsection{Metals in water and sediments of Fee-Fishing Reservoirs}

It analyzed the metals ( $\mathrm{Fe}, \mathrm{Cd}, \mathrm{Cr}, \mathrm{Zn}, \mathrm{Cu}, \mathrm{Ni}, \mathrm{Al}, \mathrm{Pb}, \mathrm{Mn}, \mathrm{Ca}$ and $\mathrm{Mg}$ ) in the fraction potentially bioavailable or weakly bound waters and sediment. The collections in this work were performed as recommended by the guide collections CETESB (1991) and APHA (1998). Water 
samples were collected with the help of Van Dorn bottle, half the height of the reservoirs, and stored in polyethylene bottles previously washed with $10 \%$ nitric acid and acidified to $\mathrm{pH} 1$ with concentrated nitric acid. The samples were digested with nitric acid, according to APHA (1998). The metals were analyzed using Optical Emission Spectrometry Coupled Plasma (ICP-OES).

The sediment samples were collected using dredges Eckman-Birge and stored in polyethylene bottles previously cleaned with $10 \%$ nitric acid. The sediments were distributed in Pyrex glass trays for the removal of unwanted materials, such as fragments of plants, boulders, among others, and previously dried at $60{ }^{\circ} \mathrm{C}$ for 24 hours in an oven with air circulation. After drying, the samples were pulverized in an agate mortar and passed through a sieve of $0.250 \mathrm{~mm}$ mesh. Then, about $2.5 \mathrm{~g}$ of sediment sample were subjected to leaching in a $50 \mathrm{ml} \mathrm{HCl} 0.1 \mathrm{~mol} \mathrm{~L}-1$, under constant stirring for two hours at $150 \mathrm{rpm}$ (GATTI, 1997). After the acid leaching, the samples were filtered through filter paper of slow filtration and conditioned in polyethylene bottles until the determination of metals. The metals were analyzed using Optical Emission Spectrometry Coupled Plasma (ICP-OES).

\subsection{Effluent of fee-fishing treated with constructed wetland system (CWS)}

A few studies have verified the effectiveness of CWSs for treatment of fee-fishing unit effluent, which is the creation of the Nile tilapia (Oreochromis niloticus), with horizontal subsurface flow, and using alternative aggregates in soil moisture filter, with- or without addition of water macrophytes such as Salvinia sp and Eichhornia crassipes (Figure 2).

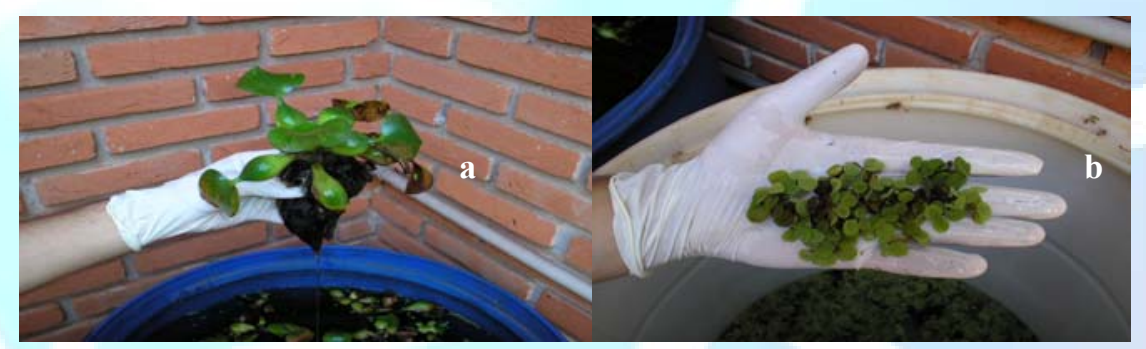

Figure 2. Macrophytes Eichhornia crassipes (a) and Salvinia sp (b) used in CWSs.

\section{RESULTS AND DISCUSSION}

\subsection{Physic-Chemical Aspects of Water in Fee-fishing Reservoirs}

The temperatures of waters and effluents during the cold/dry seasons were lower (18.2 to $28.7^{\circ} \mathrm{C}$ ) than in the rainy season $\left(23.1\right.$ to $\left.31.0^{\circ} \mathrm{C}\right)$, as was expected, and was observed in all feefishing units in the Corumbataí river basin. Mercante et al. (2005), studying fee-fishing units in the metropolitan area of Sao Paulo-SP, found values for the dry period between $18.4{ }^{\circ} \mathrm{C}$ and $26.9{ }^{\circ} \mathrm{C}$ and in rainy period $23.8^{\circ} \mathrm{C}$ and $30.0^{\circ} \mathrm{C}$, which are very close to the values it observed in this study.

Dissolved oxygen (DO) values ranged from $3.3 \mathrm{mg} . \mathrm{L}^{-1}$ to $14.5 \mathrm{mg} . \mathrm{L}^{-1}$ in the waters of feefishing reservoirs. These results were very close to those found by Mercante et al. (2005) in other units located in the great metropolis of São Paulo. CONAMA Resolution 357 (BRASIL, 2005) stipulates the maximum DO value for class 2 waters as $5.0 \mathrm{mg} . \mathrm{L}^{-1}$. The highest DO values occurred in June, when the water temperatures in the fee-fishing reservoirs were lower; this was expected, because oxygen dispersion into the reservoirs in these conditions is lower.

In general, the amount of total dissolved solids (TDS) in the waters of reservoirs in feefishing is higher than that observed in their effluents. Electrical conductivity was also checked and ranged from 17.0 to $842.0 \mathrm{Scm}^{-1}$, as this data provide important information on metabolism and can 
detect pollution sources in aquatic systems. According to the Department of Public Health, Rio Claro, these reservoirs have large amounts of fluorine and are unfit for human consumption. In some cases there was sudden increase in salinity due to the addition of salt to prevent parasites and other diseases in fish.

Presence of excessive phytoplankton attenuates penetration of light, and for depths lower than $0.40 \mathrm{~m}$ reduction of feed and fertilization is recommended making these fee-fishing units the major factors for the vigorous growth of plankton, especially phytoplankton (MERCANTE et al., 2004). The alkalinity values in all fee-fishing units studied ranged between 5.0 and $425.0 \mathrm{mg} . \mathrm{L}^{-1}$, the desirable being over $20.0 \mathrm{mg} . \mathrm{L}^{-1}$ (SIPAÚBA-TAVARES, 1994). The highest values of this activity are not the direct result of high concentrations of alkalinity, but high levels of phosphorus and other essential elements, whose presence is directly proportional to the level of alkalinity. Water with alkalinity and/or hardness lower than $20 \mathrm{mg} \cdot \mathrm{L}^{-1} \mathrm{CaCO}_{3}$ reduces buffering capacity causing daily fluctuations in $\mathrm{pH}$, which depend on respiratory- and photosynthetic processes (KUBITZA, 2003).

Ammonia-nitrogen in all fee-fishing reservoirs ranged between 0.04 and $2.20 \mathrm{mg} . \mathrm{L}^{-1}$, well above the ceiling of $0.02 \mathrm{mg} . \mathrm{L}^{-1}$ prescribed for water class 2 by CONAMA Resolution 20/86, (BRASIL, 1986). It can be concluded that the fish in all the fee-fishing units in the Corumbataí river basin were exposed to these lethal levels. High values of nitrite were observed in most fee-fishing reservoirs compared to those in water supply and wastewater generated. At no time, however, was the limit set by CONAMA Resolution 357 (BRASIL, 2005) of $1.0 \mathrm{mg} . \mathrm{L}^{-1}$ exceeded. SipaúbaTavares (1994) recommends for fee-fishing reservoirs that nitrite tolerance values remain within 0.5 $\mathrm{mg} \cdot \mathrm{L}^{-1}$.

Nitrate values above $5.0 \mathrm{mg} . \mathrm{L}^{-1}$ indicate poor sanitation of reservoirs, which is not the case in this fee-fishing study. CONAMA Resolution 357 (BRASIL, 2005) stipulates $10.0 \mathrm{mg} . \mathrm{L}^{-1}$ as the highest value for class 2 waters, so the water samples in the fee-fishing units were within this standard stipulated by federal law $\left(0.1\right.$ and $\left.4.0 \mathrm{mg} . \mathrm{L}^{-1}\right)$. Nitrates could have different sources, one of which is organic matter found in the soil, and high rates of nitrate in water are harmful to humans and lethal to unborn babies.

CONAMA Resolution 357 (BRASIL, 2005) stipulates $0.5 \mathrm{mg} . \mathrm{L}^{-1}$ as the limit for total nitrogen and: at $\mathrm{pH}>8.5,1.0 \mathrm{mg} . \mathrm{L}^{-1}$ at $8.0<\mathrm{pH} \leq 8.5 ; 2.0 \mathrm{mg} . \mathrm{L}^{-1}$ at $7.5<\mathrm{pH} \leq 8.0$ and $3.7 \mathrm{mg} . \mathrm{L}^{-1}$ at $\mathrm{pH} \leq 7.5$. With a few exceptions, the amount of total nitrogen in the water supply and drains in feefishing reservoirs were within the limits allowed by current legislation. Nitrogen is important because it is a limiting factor from the health point of view, and its rise leads to increased proliferation of microorganisms leading to increased biochemical oxygen demand (BOD).

The total phosphorus limit value at $30 \mu \mathrm{g} . \mathrm{L}^{-1}$ CONAMA Resolution 357 (BRASIL, 2005), thereby putting all waste generated from fee-fishing units in the Corumbataí river basin outside the limit permitted by federal law. In some samples, the values found for the phosphorus ranged up to about 20 times greater than that allowed by current law. High concentrations of phosphorus or its derivatives are associated with eutrophication, causing growth of algae or other aquatic organisms in dangerous stagnant water reservoirs. As with turbidity, the values of apparent color found in almost all fee-fishing also exceeded the limit of $75 \mathrm{PTL}^{-1}$ set by CONAMA Resolution 357 (BRASIL, 2005). This Resolution stipulated the limit of 100 UNT for turbidity of class 2 water and our findings in most cases were above this limit.

McIntosh (2000) cited that the food supplied to fish is an important form of pollution in farming systems, increasing concentrations of organic matter and nutrients and are caused by the loss and excretions of farmed animals. Continuous renewal of water in the ponds can minimize the eutrophication effects by preventing the excessive deposition of material on the reservoir bottom as well as the decomposition of oxygen consumed. 


\subsection{Biological Aspects of Waters}

The values it found for total coliforms ranged between 86.0 and $24,192.0$ NMP. $100 \mathrm{~mL}^{-1}$. One of the anxieties of fee-fishing is that the mine that supplies the property is contaminated, and exceeds the total coliforms limit established for class 2 waters. Those years ago this same mine had qualified the conditions laid down for a spa is evidence of an accelerated degradation of groundwater in the Corumbataí river basin. Besides the intense agriculture and mining carried out in the region, the municipality of Rio Claro allowed the construction of residences on the plateaus of hills with steep slopes, with no sanitation infrastructure.

The total coliform level in water must be related to the type of use; the presence of these bacteria indicates some kind of contamination from E. coli and confirms the presence of fecal pollution such as from the feces of warm-blooded animals or sewage. The CONAMA Resolution 357 (BRASIL, 2005) limit for total coliform in class 2 freshwater is 5,000 NMP.100mL $\mathrm{m}^{-1}$. The results found in water- and sewage samples from the reservoirs of fee-fishing exceeded this limit allowed by law. However, the $E$. coli values of any sample of water or wastewater in the reservoirs were in excess of the maximum allowed for class 2 water $\left(1,000 \mathrm{NMP} .100 \mathrm{~mL}^{-1}\right)$, referred above.

The biochemical oxygen demand (BOD) values found in all samples were above the maximum allowed for class 2 water, or $5 \mathrm{mg} \mathrm{L}^{-1}$ prescribed by law. These results indicate the presence of large amounts of organic matter in the reservoirs, probably due to excess intake, leading to nutrient enrichment. The proliferation of microorganisms, animals, plants, and heterotrophs reduce dissolved oxygen to almost zero and is related to the amount of organic matter present in the spring (PORTUGAL FILHO, 2006).

The results for total pigments also showed nutrient enrichment in the reservoirs, because compared to the same values for inputs and effluents an increase of primary production was evident. As regards the limit set by law for class 2 freshwater $\left(30 \mu \mathrm{g} . \mathrm{L}^{-1}\right)$. The situation is so alarming in the fee-fishing reservoirs in the Corumbataí river basin, as the level reached is $523.6 \mu \mathrm{g}$. $\mathrm{L}^{-1}$ owing to the presence of an intense greenish tinge. While toxicity tests were performed on all samples collected throughout the monitoring period, in no sample was there indication of pollution by micro crustaceans Daphnia similis.

\subsection{Trace Metals in Water and Sediments in Reservoirs}

It seeks to quantify the concentrations of bioavailable elements $(\mathrm{Cd}, \mathrm{Cr}, \mathrm{Cu}, \mathrm{Fe}, \mathrm{Zn}, \mathrm{Ni}, \mathrm{Pb}$, $\mathrm{Al}, \mathrm{Mn}, \mathrm{Ca}$ and $\mathrm{Mg}$ ) in water samples and sediments of the fee-fishing reservoirs in Corumbataí river basin. Metals due to their toxicity have the potential for bioaccumulation and persistence in the environment, and require close attention to minimize possible damage to the quality of life. Investigation of environmental pollution caused by metals is a subject of great interest.

In many fee-fishing facilities, levels in excess of the limits established by CONAMA Resolution 357 (BRASIL, 2005) for class 2 water bodies were detected for $\mathrm{Ca}, \mathrm{Mg}, \mathrm{Al}, \mathrm{Zn}, \mathrm{Mn}$, and $\mathrm{Fe}$ but not for $\mathrm{Cd}, \mathrm{Ni}, \mathrm{Cr}, \mathrm{Pb}$, and $\mathrm{Cu}$. Only $\mathrm{Zn}$ concentrations exceeded the CONAMA prescribed limit in all fee-fishing reservoirs. With the exception of $\mathrm{Ca}$ and $\mathrm{Mg}$, the quantities of potentially bioavailable metals varied among the various fee-fishing reservoir samples collected. There were no differences in the trace metal quantities between the dry/cold and rainy/hot seasons. All metals were detected in the sediment samples analyzed. Even $\mathrm{Cd}$, a highly toxic metal, was found in the sediments. There is no national legislation on the quality of sediments although they are part of the natural environment. So it was only possible to compare them with results from studies conducted in other watersheds by means of pellets.

\subsection{Socioeconomic Characteristics of Fee-fishing}

Most owners of fee-fishing units already owned a farm and decided to invest in an activity that gave them pleasure $(27 \%)$, in addition to economic reasons $(33 \%)$. Other options were the 
desire to diversify production, the success of others or, to invest in profitable business. In most feefishing units the owners were primarily responsible for the legalization of the project, according to data collected with questionnaires, and then the technical expertise $(33 \%)$ or specialized companies $(20 \%)$. However, the veracity of these responses is doubtful, because in the bodies of entries there are processes for such legalization.

It was found that the vast majority of fee-fishing units does not provide technical assistance and export (73\%). These situations, in general, were consistent with those identified by Venturieri (2002) who investigated the state of affairs of fee-fishing facilities in the State of Sao Paulo. The owners established the fee-fishing units with their own resources $(73 \%)$ in the Corumbataí river basin, and a small proportion availed some type of financing, which indicates the difficulties of this sector in obtaining affordable credit. The education levels of fee-fishing owners vary greatly, most of them only having completed the secondary school grade. The major occupation of the owners fell into seven categories, of which $39 \%$ were traders and farmers only $7 \%$.

Of the access to fee-fishing facilities are $67 \%$ of asphalt- and dirt roads, while $20 \%$ are exclusively dirt roads. The presence of fee-fishing facilities is prominent in the municipality of Rio Claro, a total of 10 fee-fishing units, representing about $67 \%$ of the total (16) are found in the Corumbataí river basin.

Most properties opt for the fee-fishing system with $70 \%$ of these options and work all days of the week $(73 \%)$, or six days with one day for the reception and handling of fish. Only a small number are open on Saturdays and Sundays. In many cases, what distinguishing feature of one category from the other are quality and not the type of installation. The owners exploit the entire services fee-fishing units offer, as they constitute an important source of income. Earnings from the restaurants/cafes/bars represent $31.88 \%$ of the total monthly income of fee-fishing in the Piracicaba river basin (KITAMURA et al., 1999),

In fee-fishing units, control of number of fish/kg fish is crucial; for it is through these that the replacements are made. It is not a task easily performed, since it involves several items such as food, drinks, fishing rods, bait, and fish taken from different lakes and different types of collection and others. One of the important findings of research relates to the human resources in the feefishing outlets. The average number of employees is 5. It is important to note that a significant percentage among these employees $(62.6 \%)$ is families. Although in many fee-fishing units such employees do not receive a salary, their jobs are open; this is an aspect that deserves to be reckoned in the cost structure of the fee-fishing. Family members, who constitute $80 \%$ of fee-fishing human resources, mainly operate these enterprises these units being a family activity, and only $7 \%$ have partners.

The user profile is related to the location and is region-specific (79\%), suggesting that the fee-fishing concept is expanded in response to local demand for leisure. This justifies the proliferation of this type of development in rural areas. The user profile also shows that the vast majority is made up of middle-class patrons who come with their families $(60 \%)$ and the retiree class accounts for $7 \%$ of all fee-fishing patrons. Patrons of fee-fishing are made up of $62 \%$ men and $38 \%$ women. The average capacity of patrons at a fee-fishing is 167.5 people - a considerable capacity, which if filled would add up to 2512.5 .

The average investment for setting up a fee-fishing facility in the Corumbataí basin is $\mathrm{R} \$$ $124,000.00$, a significant sum in the current state of the economy. In the monthly expenses of a feefishing operation the purchase of fish (78\%) predominates, followed by outgo on electricity and food ( $8 \%$ each), and bait (6\%). Several difficulties arise, the most common being the price of fish $(32 \%)$, followed by that of feed $(22 \%)$. It is reported that $65 \%$ of owners consider this activity generates little profit, $14 \%$ believe that there is loss, and only $7 \%$ believe that there is profit.

Concerning control of water quality of both the input water and the reservoirs, it was observed in our study that $80 \%$ of fee-fishing operators claimed monitoring it, while $20 \%$ did not 
exercise any type of control. This is somewhat contradictory, as some fee-fishing carried out analysis only once (in the early stages of development), while others said they performed weekly tests of water of some parameters. The water reservoirs are mostly gravity fed $(67 \%)$, while in of $33 \%$ of cases uptake is by pumping. The water for human consumption in $60 \%$ of cases is treated (treated DAE - Division of Water and Wastewater) and $40 \%$ comes from wells. In all cases, electricity is available.

Among the parameters analyzed in the reservoirs, 33\% measure the $\mathrm{pH}$ and $26 \%$ of cases, dissolved oxygen and temperature. These three parameters are important for assessing the water quality and are required to ensure a typical pattern for health of the fish; moreover, the tests are inexpensive and easy to perform. The management of reservoirs is essential for maintaining water quality suitable to the fish, while $39 \%$ use aerators in the reservoirs to augment the amount of dissolved oxygen. Here lies another legal difficulty, as this activity needs no authorization from the CETESB.

The mortality of fish in the reservoirs can be caused by poor water quality, problems in the transport of fish, parasites, and rapid changes in temperature, among other factors. When owners were asked whether there was periodic mortality of fish, 53\% replied in the affirmative and $47 \%$ in the negative. Prophylaxis is the best way to avoid problems with fish, but $47 \%$ of fee-fishing operators do not practice it. Among the preventive measures, $44 \%$ of fee-fishing s adopt rock salt, $40 \%$ the use of lime, $12 \%$ use traditional medicines for fungus and $4 \%$ use of vitamins in the diet.

Of the fee-fishing properties in the Corumbataí river basin, $37 \%$ have riparian forests, but with few trees, 33\% have reared other animals along the reservoirs, such as horses, birds, cows which may be the cause of total coliforms present in some of the units studied, and $30 \%$ have established the presence of wild animals such as herons, capybaras, otters, and others.

The environmental protections laws are to ensure that the measures to prevent and correct some damage are instituted, and $87 \%$ of operators have clear knowledge of the subject. Now as to the laws relating to water quality, $60 \%$ do not have any knowledge of the laws in force. In addition, $57 \%$ of owners admitted the need for greater environmental awareness, $31 \%$ required more planting of trees, and $6 \%$ came out in favor of mandatory treatment of effluents from the fee-fishing facilities. These are responses of just some of the owners of those wanting to build a fee-fishing because of reasons such as "love what you do", "do not pollute," "having money", "study fish", "inquire" and "evaluate the competition."

\subsection{Fish Species Found in Fee-fishing}

Lima-Junior (2003) in his study "The communities of fish and water quality in parts of Corumbataí-SP" found the only exotic species, i.e., the tilapia, Oreochromis niloticus (Linnaeus, 1758). This species is found in all fee-fishing units in the Corumbataí river basin. He established that of the 16 fee-fishing s found, and thus fry or even large fish escape. Several species of fish were found in the fee-fishing reservoirs (Table 1). It is therefore possible to establish a direct relationship between them and the findings of Lima-Junior (2003), besides the accidental leaks likely to occur in these units.

\subsection{Effluent of fee-fishing treated with constructed wetland system (CWS)}

In most fee-fishing facilities located in the Corumbataí river basin for 18 months, the pollutant load was above the limits allowed by legislation for class 2 water. This is worrisome because the effluent from fee-fishing is carried over to water bodies and the pollutant load, directly or indirectly, contributes to their pollution. Excessive amounts of cyanobacteria reduce dissolved oxygen levels at night and could also indicate the presence of pathogenic organisms or algae that cause unpleasant taste and odor to the fish in the water. 
None of the fee-fishing facilities currently active in the Corumbataí river basin treats its effluent, and possibly contributes to the increase of the pollutant load in that water body. Excess nutrients in the effluent of their reservoirs contribute to eutrophication, reduced water quality in rivers of the basin. The constructed wetland system (CWS) has successfully applied as secondary or tertiary treatment of residue or effluents.

Table 1- Species of fish found in fee-fishing units in Corumbataí river basin

\begin{tabular}{lll}
\hline$N^{\mathbf{0}}$ & \multicolumn{1}{c}{ COMMON NAME } & \multicolumn{1}{c}{ SCIENTIFIC NAME } \\
\hline 1 & Nile Tilapia & Oreochromis niloticus (Linnaeus, 1758) \\
2 & Pacu & Piaractus mesopotamicus (Halmberg, 1887) \\
3 & Tambacu & Híbrido (pacu X tambaqui) \\
4 & Sant Peter & Híbrido (vários cruzamentos) \\
5 & Head carp, great & Aristichthys nobilis (Richardson, 1824) \\
6 & Grass carp & Ctenopharyngodon idella (Valenciennes, 1844) \\
7 & Tambaqui & Colossoma macropomum (Cuvier, 1818) \\
8 & Common carp & Cyprinus carpio (Linneaus and Heckel, 1843) \\
9 & Piau & Leporinus piau (Fowler, 1941) \\
10 & Tetra (Lambari) & Astyanax sp. (Linneaus, 1758) \\
11 & Matrinxã & Brycon cephalus (Günther, 1869) \\
12 & Curimbatá & Prochilodus lineatus (Valenciennes, 1836) \\
13 & Pintado & Pseudoplatystoma corruscans (Spix and Agassiz, 1829) \\
14 & Cachara & Pseudoplatystoma fasciatum (Linneaus, 1766) \\
15 & Gold & Salminus brasiliensis (Cuvier, 1816) \\
16 & Catfish & Ictalurus punctatus \\
\hline
\end{tabular}

In the early days of the inception of CWSs, few decreases were observed in biochemical oxygen demand, total nitrogen, total phosphorus, ammonia, nitrite, nitrate, and increased dissolved oxygen. It is necessary to first stabilize the system, then to establish the functioning of the system used. Most of the maximum efficiency was recorded after 10 days of the system's operation, which may be explained by this stabilization, enabling a dynamic equilibrium between soil filter plants and the microorganism population contained therein.

The use of system constructed wetlands "Constructed Wetland System" (CWS) is considered an alternative technology for wastewater treatment, developed mainly from the 70s. Systems of natural- and constructed wetlands have shown high capacity to process recycle, retain and remove different types of pollutants, especially organic ones (WALLACE, 1998), and eutrophying nutrients and fecal contamination of sewage and surface waters, based on natural processes (filtration, sedimentation, adsorption/absorption, biodegradation) that occur in microbial biofilms formed between the rhizosphere and the solid substrate (TANNER, 1996; GOPAL, 1999). Recently, CWS has been successfully deployed for the treatment of agricultural-, industrial-, and domestic waste (SCHULZ et al., 2003; MICHAEL, 2003).

Some parameters (total nitrogen, suspended solids, COD, turbidity, and apparent color) showed significant efficiencies from the beginning of the experiment, which may have occurred because of the type used to CWS, and horizontal subsurface flow, with oxygenation and water retention time of 2 days. The boxes containing soil filters and macrophytes, Salvinia sp and Eichhornia crassipes were utilized, but after 60 days either the presence of Lemna sp was observed. This macrophyte initially imperceptible was among the others, but its growth was very slow. Thus, the treatment adopted of mixed culture of two macrophytes, brought results in the form of the presence of three macrophytes Salvinia sp, Eichhornia crassipes and Lemna sp. During the 
experiment, however, macrophytes species Salvinia sp and Lemna sp, more adapted to local environmental conditions, predominated.

These results demonstrated the efficacy of CWS with horizontal subsurface flow of feefishing wastewater treatment, and highlighted the need for use of macrophytes to achieve considerable reduction in parameters of water quality indicators. As this system is not very effective for phosphorus and its derivatives, there is need to understand the process better to optimize these results.

\section{CONCLUSION}

Among the main environmental impacts identified as resulting from the activities performed in fee-fishing units are use of diet in excess of the daily needs of fish, indiscriminate use of algaecides, bactericides and fungicides, which are also pollutants, carcinogens, mutagenic and teratogenic; utter disregard of the margins of reservoirs; inappropriate destination of the remains of fish after cleaning of reservoirs; destination inadequate sediment removal from the reservoirs after cleaning them up, and absence of monitoring of disease in fish and sources of pollution. There is need to include use planning and land use in the rural area Master Plans of municipalities. The effluent generated in the fee-fishing units is not within the class 2 defined by CONAMA Resolution 357 (BRASIL, 2005), and require pre-treatment.

In conclusion, some mitigation measures relevant to the activities of fee-fishing in the Corumbataí river basin are proposed: improvement and facilitation of the mechanisms relating to the legalization of fee-fishing through government, improving environmental conditions of feefishing units, implementation of measures to mitigate environmental impacts, such effluent treatment; greater care to avoid any escape of fish species alien to the bodies of water adjacent to the fee-fishing units, reforestation, control of inputs available in the reservoirs for various purposes, greater control of hygiene and other measures to improve public health, environmental education and effective training, improved human resource in farming and the trade and changes in reservoir management practices to minimize pollution by effluents.

\section{ACKNOWLEDGEMENTS}

We would like to thank FAPESP for the Scientific Initiation scholarship granted and FUNDUNESP and FEHIDRO for supporting the research.

\section{REFERENCES}

\section{APHA - AMERICAN PUBLIC HEALTH ASSOCIATION -. Standard methods for the examination of water and wastewater. 20th ed. Washington: American Public Health} Association; AWWA; WPCF, 1998. 1569p.

BRASIL. Resolução $\mathbf{n}^{\mathbf{0}}$ 357, 17 março de 2005. Dispõe sobre a classificação dos corpos de água e diretrizes ambientais para o seu enquadramento, bem como estabelece as condições e padrões de lançamento de efluentes, e dá outras providências. Resoluções do CONAMA - Conselho Nacional do Meio Ambiente - Ministério do Meio Ambiente -. Brasília, DF; SEMA, 2005. 23p. Disponível em $<$ http://www.mma.gov.br/port/conama/res/res05/res35705.pdf $>$. Acesso em 28 mai 2009. 
BRASIL. Resolução no 20, 18 de junho de 1986. Resoluções. Classificação das águas doces, salobras e salinas no Território Nacional. do CONAMA - Conselho Nacional do Meio Ambiente Disponível em: $<$ http://www.mma.gov.br/port/conama/res/res86/res2086.html $>$ Acesso em 26 mai 2009.

CETESB - COMPANHIA DE TECNOLOGIA E SANEAMENTO AMBIENTAL Água - Teste de toxicidade aguda com Daphnia similis, Lei 5.018. São Paulo: CETESB, 1991. 33p.

ELER, M.N.; GAETA, E.L.; SENHORINI, J.A.; SERAFIN, D.R.; BUFON, A.G.M. Avaliação do Impacto Ambiental de Pesque-pague na Bacia do Mogi-Guaçu. Práticas I. Congresso Estadual de Comitês de Bacias Hidrográficas. Pirassununga. 2001. 47p.

FERNANDES, R.; GOMES, L.C.; AGOSTINHO, A.A. Pesque-pague: negócio ou fonte de dispersão de espécies exóticas?Acta Scientiarum: Biological Sciences, Maringá, v.25, p.115-120, 2003.

GARCIA, A.M.; LOEBMANN, D.; VIEIRA, J.P.; BEMVENUTI, M.A. First records of Introduced carps (Teleostei, Cyprinidae) in the natural habitats of Mirim and Patos Lagoon estuary, Rio Grande do Sul, Brazil. Revista Brasileira de Zoologia, v. 21, p.157-159, 2004.

GATTI, L.V. Distribuição de Metais em Sedimentos, Datados por 210PB, de Lagoas Marginais ao Rio Mogi-Guaçu (E.E. de Jataí, Luiz Antônio, SP.) 1997. 146 f. Tese (Doutorado em Química) - Departamento de Química, Universidade Federal de São Carlos, São Carlos, SP. 1997.

GOPAL, B. Natural and constructed wetlands for wastewater treatments: potentials and problems. Water Science and Technology, London, v.40, n.3, p. 27-35, 1999.

KITAMURA, P.C., LOPES, R.B., CASTRO JR., F. G.; Queiroz, J.F. Avaliação ambiental e econômica dos lagos de pesca esportiva na bacia do Rio Piracicaba. Boletim de Indústria Animal. Piracicaba, v.56, n.1, p. 95-107, 1999.

KUBITZA, F. Qualidade da água no cultivo de peixes e camarões. Jundiaí: Kubitza, 2003. 229p.

LIMA-JUNIOR, S.E. As comunidades de peixes e a qualidade da água em trechos do Rio

Corumbataí-SP. Relatório de Pesquisa. Processo FAPESP 99/11459-5. UNESP, Rio Claro. 192p. 2003.

MARKER, A.F.H.; NUSCH, E.A.; RAI, H.; RIEMANN, B. The measurement of photosynthetic pigments in freshwaters and standardization of methods: conclusions and recommendations. Arch Hydrobiol. Beih. Ergebn. Limnol. v.14, p.91-106, 1980.

McINTOSH, R.P. Changing paradigms in shrimp farming: Low protein feeds and feeding strategies. The Advocate, p. 48-50, 2000.

MERCANTE, C.T.J.; COSTA, S.V.; SILVA, D.; ÂNGELA, M. Water quality in fee-fishing ponds located in the São Paulo metropolitan region, Brazil: analysis of the eutrophication process. Acta Limnologia Brasiliensia. Botucatu, v.16, p. 95-102. 2004. 
MERCANTE, C.T.J.; COSTA, S.V.; SILVA, D.; CABIANCA, M.A.; ESTEVES, K.E. Qualidade da água em pesque-pague da região metropolitana de São Paulo (Brasil): avaliação através de fatores abióticos (período seco e chuvoso). Acta Scientarum: Biological Sciences. Maringá, v.27, p.1-7, 2005.

MICHAEL, J.H.J. Nutrients in salmon hatchery wastewater and its removal through the use of a wetland constructed to treat off-line settling pond effluent. Aquaculture: An International Journal Devoted To Fundamental Aquatic Food Resources, Amsterdam, v. 226, p. 213-225, 2003.

PALMA-SILVA, G.M.; TAUK-TORNISIELO, S.M. Contribuición de las áreas urbanas en la polución del rio de Corumbataí, SP, Brazil. In: Contribución a la educación y la protección ambiental v.2, vII Taller, p. 1-9. 2001.

PORTUGAL FILHO, G. GPCA - Meio Ambiente. Disponível em:

$<$ http://www.gpca.com.br/poluicao2.htm> Acesso em: 14 Jul. 2009.

SCHULZ, C.; GELBRECHT J.; RENNERT B. Treatment of rainbow trout farms effluents in constructed wetland with emergent plants and subsurface horizontal water flow. Aquaculture: An International Journal Devoted To Fundamental Aquatic Food Resources, Amsterdam, 217, p. 207-221, 2003.

SIPAÚBA-TAVARES, L.H.E. Limnologia aplicada à aqüicultura. Jaboticabal, Funep. 1994.

SIPAÚBA-TAVARES, L.H.E. Utilização de biofiltros em sistemas de cultivo de peixes. Informe Agropecuário, Belo Horizonte, v.21, p.38-43, 2000.

TANNER, C.C. Plants for constructed wetland treatment systems: A comparison of the growth and nutrient uptake of eight emergent species. Ecological Engineering: The Journal of Ecotechnology, Oxford, v.7, p. 59-83, 1996.

VENTURIERI, R. Pesque e Pague no Estado de São Paulo. São Paulo: Eco Associação para Estudos do Ambiente. 2002.151p.

WALLACE, S. Putting wetlands to work. New York: American Society of Civil Engineers, 1998. $190 \mathrm{p}$. 